\title{
A CASE OF CUSHING'S SYNDROME WITH PIGMENTATION AND SEVERE HYPOKALAEMIC ALKALOSIS
}

\author{
BY \\ A. W. B. EDMUNDS, K. C. McKEOWN, AND P. N. COLEMAN \\ From the Friarage Hospital, Northallerton
}

(RECEIVED FOR PUBLICATION SEPTEMBER 18, 1957)

Hypokalaemia is the most important result of the adrenal hyperfunction seen in the recently described Conn's syndrome (Conn and Louis, 1956). In this syndrome aldosterone is produced excessively, but evidence of the same excess of other hormones is lacking and the excretion of 17-ketosteroids and 17-ketogenic steroids in the urine is normal. Hypokalaemia may also occur in cases with a high urinary excretion of 17-ketosteroids and 17-ketogenic steroids, associated in some cases with the classical clinical features of Cushing's syndrome and in others with few or none of these features (Sprague and Power, 1953 ; Brooks, McSwiney, Prunty, and Wood, 1957; Foye and Feichtmeir, 1955). In one of these cases excess aldosterone was demonstrated (Brooks et al., 1957) and in another excess mineralo-corticoid (Foye and Feichtmeir, 1955).

The case to be described had some of the features of Cushing's syndrome and presented a hypokalaemic alkalosis more severe than has been described in either Conn's or Cushing's syndrome. In addition there was a melanin pigmentation with a distribution and intensity similar to that seen in Addison's disease. Subtotal adrenalectomy has been effective in reversing all the abnormal features, including the pigmentation.

\section{Case Report}

The patient, a married woman aged 42 years, was admitted to the Friarage Hospital, Northallerton, on August 30, 1956. For a year she had felt irritable and depressed but did not become really ill until six weeks before admission. During these six weeks she developed increasing lassitude. She lost nearly a stone in weight and transient swelling of the face and ankles was seen. Increasing pigmentation was first noticed three weeks before admission and about this time there was some dysuria and frequency and a complaint of thirst. Just before admission the patient became slightly confused mentally. Her loss at each menstrual period had been normal, but during the year before admission the intervals between the periods had increased.

On admission she was lethargic and depressed, but showed no gross muscular weakness. There was marked pigmentation of the face, at various pressure sites on the trunk (Fig. 1), on the areolae of the breasts, and on small areas of the mucous membrane inside both cheeks. She was well nourished (10 st. $10 \mathrm{lb}$.) and showed no abnormal deposits of fat, no kyphosis, and only one small cutaneous stria. The body hair was normal in amount and distribution, but she had a slight, and recent, growth of hair on the upper lip. There was no acne. Blood pressure was $140 / 80 \mathrm{~mm}$. Hg. Clinical examination revealed no other abnormality. All the deep reflexes were present, and Chvostek's and Trousseau's signs were

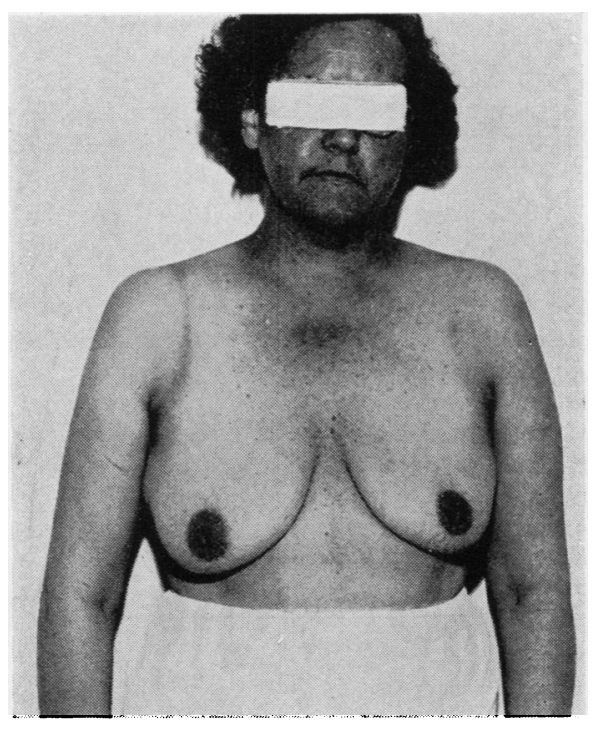

FIG. 1.-The patient on admission. The configuration of the face neck, and shoulder does not suggest Cushing's syndrome. Note pigmentation of face, exposed area of neck, and line of pressure from shoulder strap. 


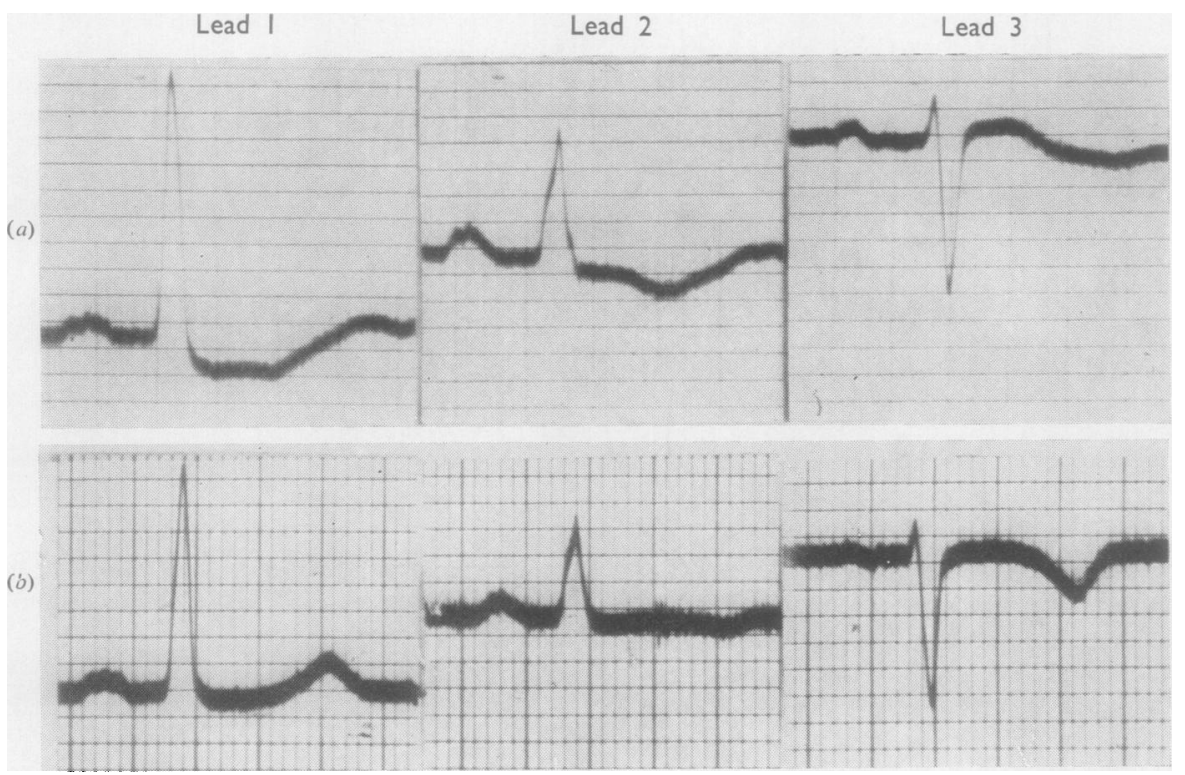

FIG. 2.-Electrocardiographs (a) on August 30 showing gross changes typical of potassium deficiency (serum potassium $1.3 \mathrm{mEq}$. Litre); $(b)$ on September 2, when standard leads have become normal with the attainment of normal blood levels for potassium (serum potassium $5.6 \mathrm{mEq}$./litre) although it is highly probable that there was at this time a considerable deficiency of intracellular potassium.

negative. The urine contained sugar and albumin and a moderate number of pus cells and gave a growth of Bact. coli on culture.

Addison's disease seemed the probable diagnosis on clinical grounds, but the laboratory findings on the day of admission, far from confirming this, gave results that suggested adrenal hyperfunction, and were as follows: Serum potassium, $1.3 \mathrm{mEq}$./litre, serum sodium, $148 \mathrm{mEq}$./litre, serum chloride, $83 \mathrm{mEq}$./ litre, serum bicarbonate, $52 \mathrm{mEq}$./litre. Leucocytes, 11,000 per c.mm., blood sugar, $210 \mathrm{mg} . \%$, blood urea, $27 \mathrm{mg} \%$, Hb 75\%. An E.C.G. showed changes in keeping with gross potassium deficiency (Fig. 2).

Before investigating the case further, measures were at once taken to correct the hypokalaemia. Potassium chloride by mouth, 2 g. two-hourly, was started at 11 p.m. on the day of admission. Next day the patient was very much brighter and the serum potassium level was $2 \mathrm{mEq}$./litre. Treatment with even larger doses of potassium chloride continued and within four days the serum potassium had returned to normal. Within the same period, without any administration of ammonium chloride, the severe alkalosis observed on admission disappeared and the plasma bicarbonate and chloride levels became normal.

A glucose tolerance test gave a diabetic type of curve. There were no circulating eosinophils, and the excretion of 17 -ketosteroids was $36 \mathrm{mg}$. in 24 hours. Professor F. T. G. Prunty then arranged for the estimation of the output of other steroids, including
TABLE

STEROID EXCRETION AND A.C.T.H. RESPONSE TEST ${ }^{1}$

\begin{tabular}{|c|c|c|c|c|c|}
\hline Date & $\begin{array}{c}\text { Potassium } \\
\text { Supplement } \\
\text { (mEq./ } \\
24 \mathrm{hr} .)\end{array}$ & $\begin{array}{c}\text { Dose of } \\
\text { A.C.T.H. } \\
\text { (units } \\
24 \mathrm{hr} \text { ) }\end{array}$ & $\begin{array}{c}\text { 17-Keto- } \\
\text { steroids } \\
\text { (mg./ } \\
24 \mathrm{hr} .)\end{array}$ & $\begin{array}{c}17- \\
\text { Ketogenic } \\
\text { Steroids } \\
\text { (mg./24 hr.) }\end{array}$ & $\begin{array}{l}\text { Aldo- } \\
\text { sterone } \\
\text { (mg. } /{ }^{2} \\
24 \mathrm{hr} .)^{2}\end{array}$ \\
\hline $\begin{array}{r}\text { Pre-operc } \\
4 / 9 / 56 \\
5 / 966 \\
12 / 9 / 56 \\
13 / 9 / 56 \\
14 / 96 \\
15 / 9 / 56 \\
16 / 9 / 56 \\
17 / 9 / 56\end{array}$ & \begin{tabular}{|c} 
ative \\
Nil \\
445 \\
Nil \\
," \\
', \\
16̆1
\end{tabular} & $\begin{array}{c}\text { Nil } \\
\text { ", } \\
\ddot{4} \\
40 \\
40 \\
40 \\
40\end{array}$ & $\begin{array}{l}30 \cdot 0 \\
35.4 \\
34 \cdot 2 \\
24 \cdot 8 \\
43 \cdot 3 \\
43 \cdot 7 \\
37 \cdot 6 \\
37.0\end{array}$ & $\begin{array}{r}\overline{90} \\
114 \\
109 \\
126 \\
68 \\
100 \\
118\end{array}$ & $\begin{array}{l}\overline{1} \\
\frac{2}{2} \\
= \\
=\end{array}$ \\
\hline $\begin{array}{l}\text { Post-oper } \\
21 / 11 / 56\end{array}$ & $\begin{array}{l}\text { rative } \\
\begin{array}{l}\text { Patient on } \\
\text { fluorohy } \\
\text { daily (no } \\
\text { appear i }\end{array}\end{array}$ & $\begin{array}{l}0.5 \mathrm{mg} .9 \alpha \\
\text { rocortisone } \\
\text { metabolites } \\
\text { urine) }\end{array}$ & $6 \cdot 8$ & 0.5 & \\
\hline
\end{tabular}

OTHER URINARY STEROIDS

Chromatography ${ }^{3}$ (Bush C system) of glucuronidase-hydrolysed urine extract indicated:

$$
\begin{array}{ll}
\text { Tetrahydrocortisone } & =5 \mathrm{mg} . / 24 \mathrm{hr} . \\
\text { Tetrahydrohydrocortisone } & =15 \mathrm{mg} . / 24 \mathrm{hr} . \\
\text { Free cortisone } & =4 \mathrm{mg} . / 24 \mathrm{hr} .
\end{array}
$$

Total $24 \mathrm{mg}$., which is greatly in excess of normal.

\section{PRE-OPERATIVE PLASMA LEVELS}

$\begin{array}{lll}\begin{array}{l}\text { Intermedin } \\ \text { (M.S.H.) }\end{array} & \ldots & \text { None found. } \\ \begin{array}{c}\text { A.C.T.H. } \\ \text { Hydrocortisone }\end{array} & \ldots & \begin{array}{l}\text { Significant amounts (more than normal). } \\ 12 \mu \mathrm{g} . / 100 \mathrm{ml} \text { (upper limit of normal } 8 \mu \mathrm{g} .\end{array} \\ \text { Corticosterone } & \ldots & \begin{array}{c}\text { Quantity present could not have exceeded } \\ 3 \mu \mathrm{g} .100 \mathrm{ml} \text {.: none found. }\end{array}\end{array}$

1 Dr. B. W. Brooks. ${ }^{2}$ Dr. I. H. Mills. ${ }^{3}$ Bush (1952). ${ }^{4}$ No standard was available as a check on identity. ${ }^{5}$ Kindly carried out by Professor F. W. Landgrebe. ${ }^{6}$ Dr. Barbara E. Clayton. 
aldosterone, and for the measurement of the effect on the 17-ketosteroid and 17-ketogenic steroid output on giving A.C.T.H. (Prunty, 1956). Professor Prunty supplied a batch of A.C.T.H. of known potency for this purpose, and at his suggestion potassium supplements were stopped during the period of the test to exclude any secondary effect on the aldosterone output from the administration of potassium in large quantities.

The results (Table) were in keeping with Cushing's syndrome. It was thought that the lack of significant response of the steroid excretion to A.C.T.H. was due to a tumour. On admission the only classical clinical features of Cushing's syndrome had been the presence of a little hair on the upper lip, but within a week this had noticeably increased, and after a further fortnight there was an obviously abnormal degree of facial hirsutism. At the same time, marked acne appeared. The blood pressure, however, always remained normal.

\section{Metabolic Studies}

Meanwhile the study of the potassium and sodium metabolism continued. The time before operation divides into two periods (periods 1 and 3 ) when the patient was receiving a large potassium supplement; and a middle period (2) when all extra potassium was omitted to facilitate the study of the steroid excretion (Fig. 3a). During periods 1 and 3 the serum potassium, initially at a low level, rapidly rose to normal when a large potassium supplement was given, only to fall equally rapidly when it was omittted. During this time a large proportion of the potassium supplement was lost in the urine, but it is clear that some was retained. (During period 1, the average potassium supplement was $254 \mathrm{mEq}$. a day and the average urine output 201 mEq. a day ; during period 3 , the supplement was $278 \mathrm{mEq}$. and the urine output 194 mEq.). The difficulty experienced by the patient in retaining potassium was illustrated in period 2 . No supplement was given and the serum potassium at once fell to $2 \mathrm{mEq}$./litre and remained at this level throughout the six-day period, yet the patient continued to excrete potassium at an average rate of $55 \mathrm{mEq}$. per day. At the same time her clinical condition deteriorated and on several occasions her legs gave way.

The serum sodium was always normal, but during period 2 it is probable that the patient was retaining sodium since

FIG. 3.-Diagram showing daily potassium supplements and serum potassium levels $(a)$ before adrenalectomy, (b) following adrenalectomy. Note that early in period 3 potassium was given for four days as enteric-coated tablets in an effort to avoid gastric irritation, but was incompletely absorbed. the average excretion on a normal ward diet was only $44 \mathrm{mEq}$. per day. During periods 1 and 3, the average excretion of sodium was at a higher level $(148 \mathrm{mEq}$. per day in period 1). In fact during the pre-operative period there was a rough parallel between the sodium and the potassium excretion. When the excretion of potassium rose as the result of the potassium supplement so also did the excretion of sodium. This effect was not seen after adrenalectomy.

Studies were also made of the sodium/potassium ratio in saliva and sweat. The results will be referred to in the discussion.

Towards the end of the first month it had become clear that an operation would be necessary. The A.C.T.H. response test suggested that the patient had an adrenal tumour, but tomograms taken after the presacral insufflation of oxygen clearly demonstrated the outlines of the adrenals and there seemed to be no tumour. An operation for the one-stage removal of the adrenals in cases of carcinoma of the breast through a semilunar incision placed transversely in the epigastrium (Fig. 6) had recently been developed here (McKeown and Ganguli, 1956). This operation allowed both adrenals to be inspected before action was taken, and meant that a pre-operative differential diagnosis between tumour and hyperplasia became less important. The operation was carried out, with Dr. K. H. Oldfield as the anaesthetist, on October 1.

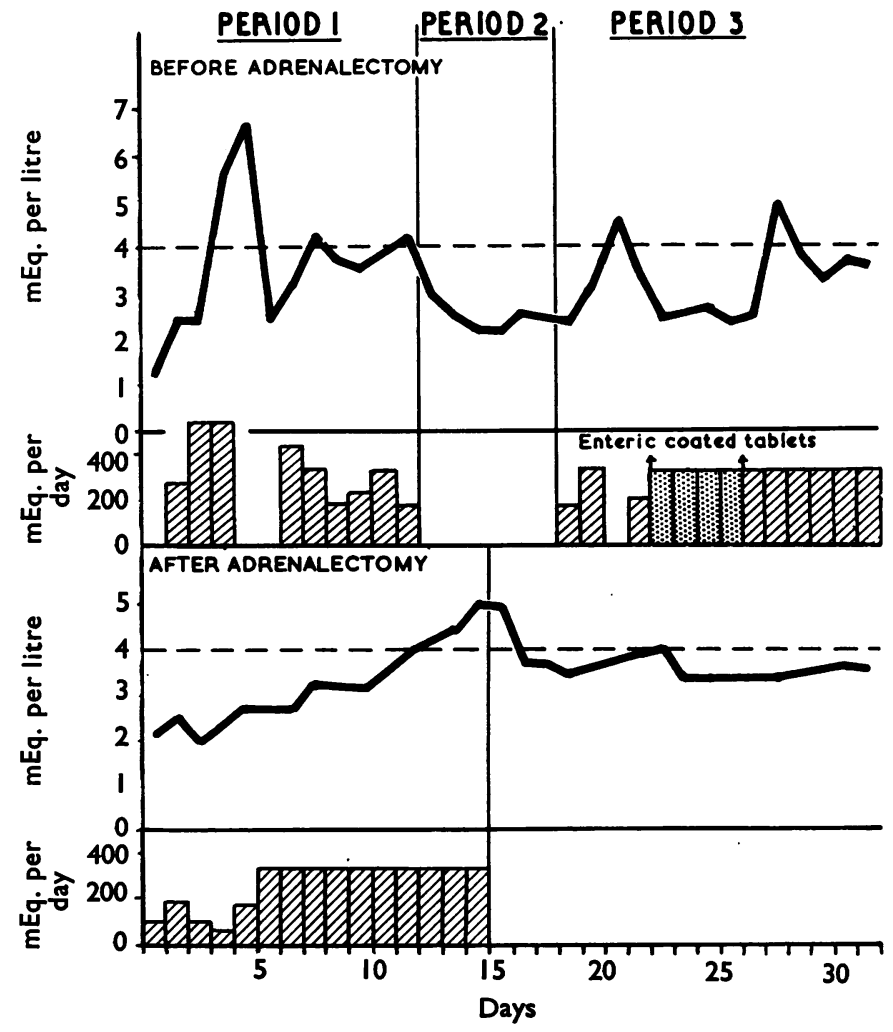




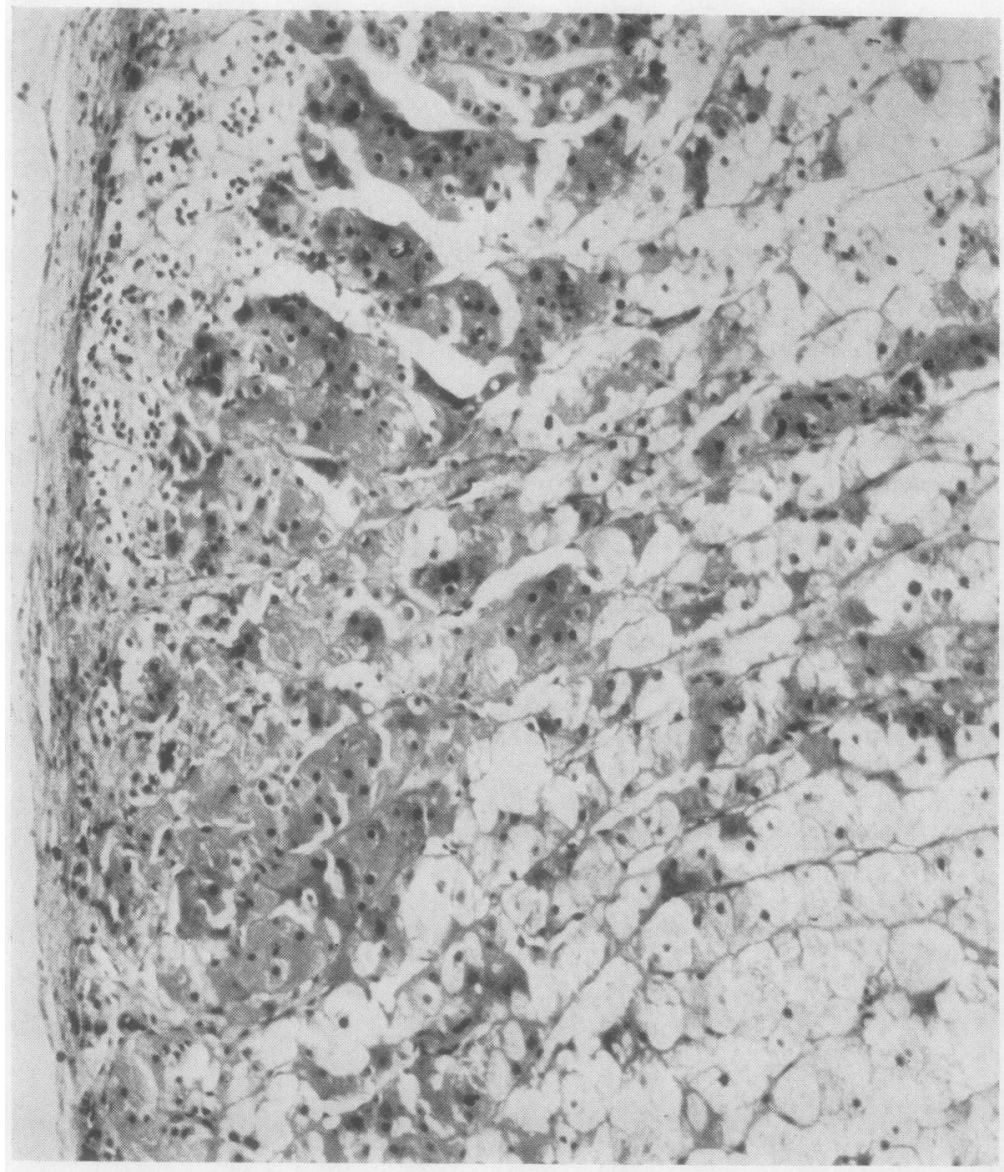

Fig. 4. - Section through the left adrenal cortex. An island of the poorly developed zona glomerulosa is seen, top left; elsewhere the zona fasciculata reaches the capsule. (Haematoxylin and eosin, $\times 150$.)

There was no tumour but both adrenals were hyperplastic. The whole of the left, and nine-tenths of the right, adrenal were removed. Biopsies were taken from the kidney, from the liver (because it looked abnormal), and from the rectus muscle.

The left adrenal weighed $15 \mathrm{~g}$. and the right $10 \mathrm{~g}$. Section showed a very considerable hyperplasia of the zona fasciculata of the cortex, but the glomerulosa was thin and poorly developed, being replaced by the fasciculata beneath the capsule in many places (Fig. 4). Frozen sections showed abundant anisotropic lipoid (Fig. 5).

Sections from the kidney biopsy showed in some degree the vacuolation of the first convoluted tubules that has been noticed in hypokalaemia (Chalmers, Fitzgerald, James, and Scarborough, 1956). The liver biopsy showed a very considerable degree of fatty infiltration.

The patient had a stormy and then difficult convalescence, but within four months her strength had returned, pigmentation had disappeared (Fig. 6), and

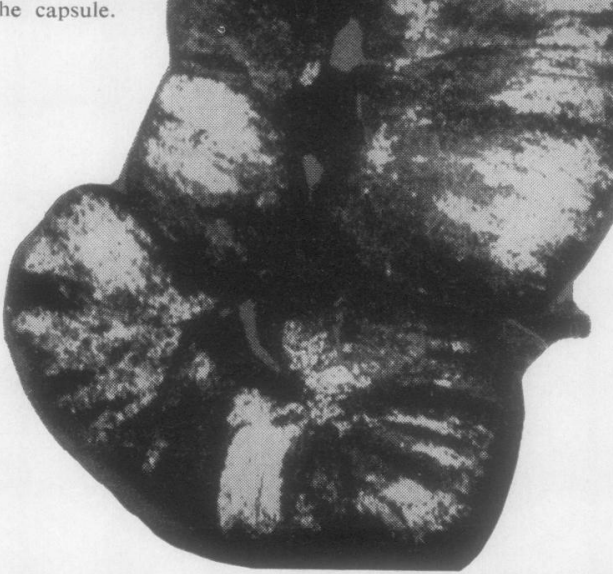

FIG. 5.-Frozen section of the left adrenal viewed throuc partially crossed polaroid screens. There is abundare anisotropic lipoid somewhat irregularly distributed ( $\times 7.5$ 


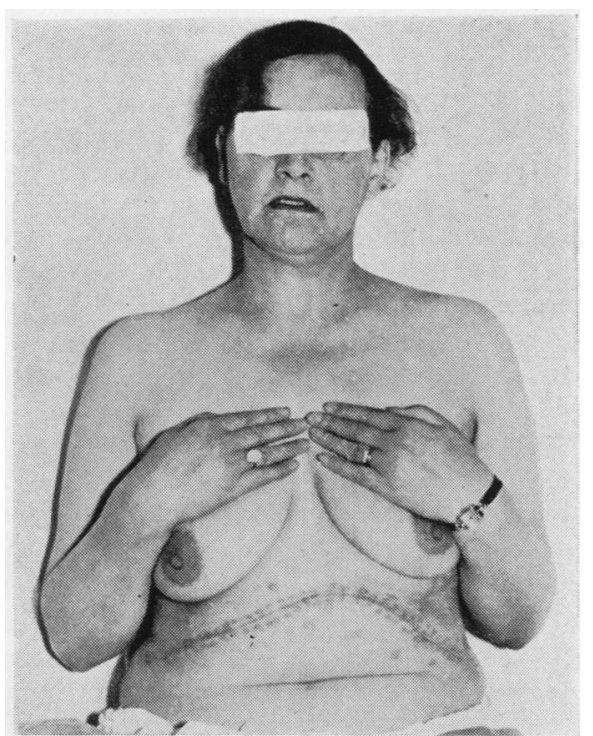

FIG. 6.-The patient five months after adrenalectomy; pigmentation has gone. The transverse scar of the operation is shown.

she was able to lead a normal life. The only disappointment has been that, in spite of efforts to leave sufficient adrenal tissue for her needs, it has not been possible to dispense with a daily maintenance dose of $37.5 \mathrm{mg}$. cortisone.

The very considerable deficit of potassium that existed at the time of operation was shown by the analysis of the muscle biopsy carried out by Mr. F. Harper, Central Clinical Laboratory, Middlesbrough. The potassium and sodium content were 34 and $51 \mathrm{mEq}$. per $\mathrm{kg}$. fresh muscle compared with average normal values of 76 and $30 \mathrm{mEq}$. per $\mathrm{kg}$. respectively (10 observations on normal muscle; for potassium, range was 51-104, standard deviation 18 ; for sodium, range 22-42, standard deviation 7.5). Some time elapsed after the operation before this deficit was corrected. Immediately after the operation the serum potassium had fallen to $2.2 \mathrm{mEq}$./litre, and. as soon as the patient could take it, the same high potassium supplement was again given. This time the serum level rose slowly, but when the normal level was attained on the 15 th post-operative day no further potassium supplements were required to sustain it (Fig. 2b). In spite of the slow rise of the serum potassium, the urine excretion rate showed that a greater proportion of the supplement than before was being retained. (Before operation, on a daily average supplement of $254 \mathrm{mEq}$. the urine output was $201 \mathrm{mEq}$.; after operation on a supplement of 245 mEq. the output was $101 \mathrm{mEq}$.)

\section{Discussion}

The case has special interest because of the two dominant features, hypokalaemia and pigmenta- tion. It was also interesting that a number of the clinical features of Cushing's syndrome were missing.

When the patient was first seen the only classical feature of Cushing's syndrome shown was a little hair on the upper lip. Possibly the rapidity of onset had left insufficient time for the other changes to occur; certainly the speed with which in the weeks following admission the growth of the facial hair increased and acne developed suggested a rapidly progressive disease. The blood pressure was always normal. Hypertension is absent in a proportion of cases of Cushing's syndrome (Cope and Raker, 1955), but has been invariable in all cases of primary aldosteronism so far described. In view of the close similarity of the electrolyte picture in the present case to that seen in aldosteronism, it seems surprising that there was no hypertension.

The Electrolyte Disturbance.-The pattern of the electrolyte disturbances was exactly similar both qualitatively and quantitatively to that observed in cases of Conn's syndrome. One of the features, well illustrated in the present case, has been the subject of comment by Prunty and his colleagues (Ager, McSwiney, and Prunty, 1956). They draw attention to the rapid rise to normal of the serum level that is seen on administration of potassium in cases of hypokalaemia due to endocrine dysfunction. This is contrasted with the slower rise seen in potassium depletion due to other causes (chronic diarrhoea, pyelonephritis). The authors consider that the difference suggests a decreased transfer of potassium to the intracellular pool in the former group. In this patient the period immediately following operation, when the serum potassium rose but slowly in spite of large supplements, can be compared to the latter type of case since at this time the endocrine dysfunction had been corrected by adrenalectomy but the patient was depleted of potassium.

An abnormally high secretion of potassium in saliva and sweat is among the recognized effects of primary aldosteronism (Milne and Muehrcke, 1956). Abnormal sodium and potassium ratios were observed in the present case and corresponded very closely with the findings described in cases of aldosteronism. Observations on the $\mathrm{Na} / \mathrm{K}$ ratio in the saliva on a number of occasions before operation were compared with observations made on saliva from normal subjects and on the patient after adrenalectomy. As has been found by other workers (Pawan, 1955 ; Eales and Linder, 1956), the wide variations in the results obtained on different occasions both in the patient 
and in normal subjects limited the value of observations on saliva as a method of demonstrating endocrine dysfunction. Nevertheless it was possible to demonstrate that both the mean values and the range of the salivary $\mathrm{Na} / \mathrm{K}$ ratios in the patient before adrenalectomy were low compared with normal subjects and returned to normal following adrenalectomy. The results obtained were as follows (10 observations in each series): Before adrenalectomy the mean $\mathrm{Na} / \mathrm{K}$ ratio was 0.27 with a range of 0.11 to 0.37 , standard deviation 0.13 , as compared with a mean for normal subjects of 0.36 , range 0.25 to 0.47 , standard deviation 0.06. After adrenalectomy the mean value for the patient was 0.35 , range 0.26 to 0.51 , standard deviation 0.06. (A simple technique for the determination of the $\mathrm{Na} / \mathrm{K}$ ratio in sweat was employed, the sweat being collected on a filter paper held in the axilla.) Two observations gave $\mathrm{Na} / \mathrm{K}$ ratios of 1 compared with normal values of 13-16 (Cantarow and Trumper, 1955). After adrenalectomy it was not possible to obtain a satisfactory measurement of the concentration of potassium by the simple technique in use.

It is of interest that, despite the close similarity between the electrolyte picture in the present case with that of primary aldosteronism, no excessive secretion of aldosterone was found in the urine. The unreliability of present methods of aldosterone estimation must, however, be recognized and normal figures have been found in Conn's syndrome (Evans and Milne, 1954 ; Russell, Marshall, and Stanton, 1956). The question remains, therefore, whether the electrolyte changes were produced by aldosterone or by another steroid with mineralo-corticoid effect, possibly corticosterone.

It was thought that the histological appearance of the adrenals could throw light on this problem. There is evidence that in the normal adrenal aldosterone is formed in the glomerulosa (Bartter, 1956), and in the present case the appearance of the glomerulosa did not suggest hyperfunction, rather the reverse. It is possible, however, that in the abnormal adrenal aldosterone is also produced in the fasciculata. This is the opinion of van Buchem, Doorenbos, and Elings (1956), who have described the only case so far of primary aldosteronism in which over-production of hormone was due not to tumour but to hyperplasia of the glands. By the courtesy of Dr. Arends and Professor van Buchem the sections from their patient have been compared with those of our own. Their sections differ in that the zona glomerulosa can everywhere be readily made out, and in some few places is hyperplastic, but in the sections from both cases a markedly hyperplastic
zona fasciculata dominates the picture.

Pigmentation.-Pigmentation is an occasional $\overrightarrow{\vec{D}}$ feature of Cushing's syndrome. Simpson (1956) mentions pigmentation of the orbit and nipples, $\frac{C}{0}$ and Cope and Raker (1955) remark on it in a few $\overline{\bar{D}}$ of their cases but do not mention its extent. In $\widehat{\otimes}$ the present case the intensity and distribution of $\propto$ the pigmentation resembled that seen in Addison's disease.

Pigmentation in Addison's disease is now thought to be due to excessive production of $\vec{\omega}$ melanocyte-stimulating hormone by an overactive pituitary. Sulman $(1952,1956)$ was able to ? demonstrate excess in nearly all the samples of $\overrightarrow{\vec{\omega}}$ plasma from cases of Addison's disease examined. $\dot{\omega}$ $\mathrm{He}$ also found excess in the plasma in 30 out of 45 cases of Cushing's syndrome. Sulman claims that excess of melanocyte-stimulating hormone is $\frac{9}{5}$ always accompanied by excess of corticotropin and $\vec{r}$ considers that by demonstrating an excess of melanocyte-stimulating hormone it is possible to distinguish the "pituitary" from the $\vec{\bullet}$ purely "adrenal" type of Cushing's syndrome. $\$$ Geschwind, $\mathrm{Li}$, and Barnafi (1956) have reported $\square$ the isolation of pure melanocyte-stimulating hormone and find that it contains seven amino-acids which occur in an identical sequence in corticotropin. They suggest that this explains the melanocyte-stimulating activity of pure corticotropin.

It would seem probable, therefore, that the pigmentation in the present case represented pituitary overactivity. Excess A.C.T.H. was found in the plasma and may have itself been the stimulus for the pigmentation, since no excess of melanocytestimulating hormone was found in the single sample of plasma examined. It is also probable that pituitary overactivity was the reason for the failure of the urinary steroid excretion to respond to test injections of A.C.T.H. The adrenals were already responding maximally to endogenous A.C.T.H., and could do no more. An example of a similar failure of the steroid excretion to $N$ respond to A.C.T.H. in a case of adrenal hyper- $N$ function not due to adrenal tumour has been re- $N$ ported by Rosenthal (1957). In this case also $\underset{\sigma}{\sigma}$ there was a melanin pigmentation with a distribution characteristic of Addison's disease.

The disappearance of the pigmentation after adrenalectomy calls for an explanation, the more $\stackrel{?}{+}$ so since many cases of Cushing's syndrome de- 0 velop pigmentation after adrenalectomy (Sprague, $\underset{\mathbb{D}}{\mathbb{D}}$ Kvale, and Priestley, 1953 ; Hernberg, 1954). The $\frac{?}{\frac{\rho}{D}}$ answer may derive from the fact that in some $\triangle$ respects the actions of cortisone and aldosterone 
are antagonistic (Hetzel, McSwiney, Mills, and Prunty, 1956 ; Rosenbaum, Papper, and Ashley, 1955). It may be that before the operation the pituitary was overacting in an attempt to stimulate production of more cortisone to counteract the excessive mineralo-corticoid effect from other hormones. When the latter was removed by operation this stimulus to A.C.T.H. production would disappear.

\section{Summary}

A woman of 42 years with adrenal hyperplasia had pigmentation resembling that of Addison's disease, normal blood pressure, and severe hypokalaemic alkalosis. Subtotal adrenalectomy led to the restoration of normal blood chemistry and disappearance of the abnormal pigmentation.

Our thanks are due to Professor F. T. G. Prunty for his generous help and advice in the diagnosis of the case and in the preparation of this paper. We wish to thank also, in addition to those mentioned in the text, Dr. E. Gilbert for referring this patient, Dr. Simon Sevitt for his opinion on the histology, Sister Calvert, Sister Gibson, and Dr. E. R. L. Paton, of the Friarage Hospital, for their tireless efforts in caring for this patient, Mr. S. Taylor for the photography, and Mrs. R. Carver for the biochemical estimations.

\section{REFERENCES}

Ager, J. A. M., McSwiney, R. D., and Prunty, F. T. G. (1956). J. Endocr., 13, xxvi.

Bartter, F. C.'(1956). Metabolism, 5, 369.

Brooks, R. V., McSwiney, R. R., Prunty, F. T. G., and Wood, R. J. Y. (1957). Amer. J. Med., xxiii, 3, 391.

Buchem, F. S. P. van, Doorenbos, H., and Elings, H. S. (1956).

Lancet, 2, 335.
Bush, I. E. (1952). Biochem. J., 50, 370.

Cantarow, A., and Trumper, M. (1955). Clinical Biochemistry, p. 280. Saunders, Philadelphia and London.

Chalmers, T. M., Fitzgerald, M. G., James, A. H., and Scarborough, Harold (1956). Lancet, 1, 127.

Conn, J. W., and Louis, L. H. (1956). Ann. intern. Med., 44, 1.

Cope, O., and Raker, J. W. (1955). New Engl. J. Med., 253, 119 and 165 .

Eales, L., and Linder, G. C. (1956). Quart. J. Med., $25,539$.

Evans, B. M., and Milne, M. D. (1954). Brit. med. J., 2, 1067.

Foye, L. V., and Feichtmeir, T. V. (1955). Amer. J. Med., 19, 966.

Geschwind, I. I., Li, C. H., and Barnafi, L. (1956). J. Amer. chem. Soc., $78,4494$.

Hernberg, C. A. (1954), Acta endocr. (Kbh.), 16, 309.

Hetzel, B. S., MeSwiney, R. R., Mills, I. H., and Prunty, F. T. G. (1956). J. Endocr., 13, 112 .

McKeown, K. C., and G̈anguli, A. (1956). Brit. med. J., $1,1466$.

Milne, M. D., and Muehrcke, R. C. (1956). Proc. roy. Soc. Med., 46, 883.

Pawan, G. L. S. (1955). Biochem. J., 60, xii.

Prunty, F. T. G. (1956). Brit. med. J., 2,615 and 673.

Rosenbaum, J. D., Papper, S., and Ashley, M. M. (1955). J. clin. Endocr., 15, 1459.

Rosenthal, F. D. (1957). Brit. med. J., 2, 139.

Russell, G. F. M., Marshall, J., and Stanton, J. B. (1956). Scot. med. $J ., 1,122$.

Simpson, S. L. (1956). In Price's Textbook of the Practice of Medicine, ed. D. Hunter. Oxford Univ. Press, London.

Sprague, R. G., Kvale, W. F., and Priestley, J. T. (1953). J. Amer. med. Ass., 151, 629.

and Power, M. H. (1953). J.-Lancet, 73, 217.

Sulman, F. G. (1952). Acta endocr. (Kbh.), 10, 320.

- (1956). J. clin. Endocr., 16, 755. 